\title{
SYNTHESIS OF 1-HYDROXYAZETIDINES AND THEIR CONVERSION
} INTO 1,4-DIACETOXY-2-AZETIDINONES

\section{M.L.M. Pennings, D. Kuiper and D.N. Reinhoudt*}

(Laboratory of Organic Chemistry,

Twente University of Technology, Enschede, The Netherlands)

Abstract: 1-Hydroxyazetidines (b), prepared by reductive cyclization of o-benzy $2-\beta-$ tosyzoxy oximes 1 and subsequent debenzylation, can be oxidized selectively either to jour-membered cyclic nitrones ( $\underline{\theta}$ and $\underline{7})$ or to 1,4 -diacetoxy-z-azetidinones ( $\underline{\theta})$.

Recently we have reported a novel route to $N$-acetoxy $\beta$-lactams by oxidation of the corresponding four-membered cyclic nitrones $(2,3 \text {-dihydroazete } 1 \text {-oxides })^{1}$. We have also found that 1-hydroxyazetidines obtained by reduction of the corresponding four-membered cyclic nitrones, could be oxidized with Hgo to the same nitrones in almost quantitative yields ${ }^{2}$. Furthermore, the c-4 unsubstituted 1-hydroxyazetidine could be converted directly to the l-acetoxy-2-azetidinone without isolating the intermediate nitrone by reaction with two equivalents of lead tetraacetate $\mathrm{e}^{1 \mathrm{~b}, 2}$. Since the synthesis of four-membered cyclic nitrones is virtually limited to the reaction of nitroalkenes with ynamines ${ }^{3}$, an alternative and more general route to these heterocycles seemed to be the oxidation of the corresponding 1-hydroxyazetidines. We wish to report here the preliminary results of a study on the synthesis and the oxidation of 1 -hydroxyazetidines ${ }^{4}$.

We anticipated that 1-hydroxyazetidines might be synthesized by cyclization of $\gamma$-tosyloxy hydroxylamine derivatives, prepared by reduction of the corresponding oximes. Oximation of 3,3-dimethyl-4-tosyloxy-2-butanone ${ }^{5}$ gave the corresponding oxime $1 \mathrm{a}$ in a yield of $92 \%$ (m.p. $119.5-121.5^{\circ} \mathrm{C}$, from diisopropyl ether) ${ }^{6}$. Reduction of this oxime under relatively mild conditions $\left(\mathrm{NaCNBH}_{3} / \mathrm{CH}_{3} \mathrm{COOH}, 16 \mathrm{~h}\right.$ at room temperature ${ }^{8}$ ) afforded $3,4,4$-trimethylisoxazolidine 3 in a yield of $61 \%$ (b.p. $62-64^{\circ} \mathrm{C} /$ $\left.13 \mathrm{~mm} \mathrm{Hg}, \mathrm{n}_{\mathrm{D}}^{20} 1.4444\right)$. MS: $\mathrm{M}^{+} 115.10\left(\mathrm{C}_{6} \mathrm{H}_{13} \mathrm{NO}\right) .{ }_{\mathrm{H}}^{1} \mathrm{NMR} \delta\left(\mathrm{CDCl}_{3}\right) 0.97$ and 1.11 (s, $\left.6 \mathrm{H}, \mathrm{CH}_{3}\right), 1.03\left(\mathrm{~d}, 3 \mathrm{H}, \mathrm{CH}_{3}\right), 3.02(\mathrm{q}, 1 \mathrm{H}, \mathrm{H}-3), 3.58$ and $3.70(\mathrm{AB}, 2 \mathrm{H}, J=7.3 \mathrm{~Hz}, \mathrm{H}-5), 4.6$ $(\mathrm{bs}, 1 \mathrm{H}, \mathrm{NH}) . \underline{3} \cdot \mathrm{HCl}: \mathrm{dec} .>120^{\circ} \mathrm{C}$, from chloroform/ethyl acetate ${ }^{9}$. obviously the reduction of the oxime is followed by a surprizing facile cyclization of the hydroxylamine derivative 2 a via intramolecular alkylation of the hydroxylamine moiety at oxygen.

Therefore we prepared the O-benzyl oxime $1 \mathrm{~b}$ from 0 -benzylhydroxylamine and 3,3dimethy 1-4-tosyloxy-2-butanone, in a yield of $96 \%$ (m.p. 83-84.5 ${ }^{\circ} \mathrm{C}$, from diisopropyl ether $)^{9}$. Reduction of $1 \mathrm{~b}$ with $\mathrm{NaCNBH}_{3}$ in acetic acid $\left(16 \mathrm{~h}, 35^{\circ} \mathrm{C}\right.$ ) gave the 1 -ben- 

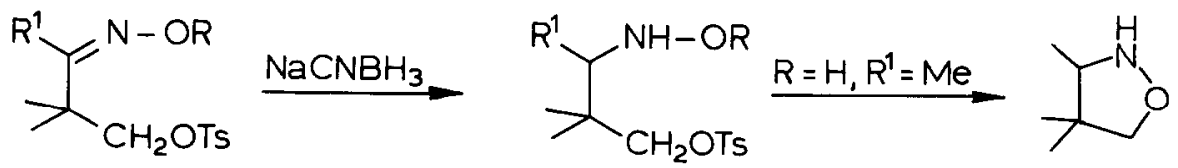

$$
\begin{aligned}
\underline{1 a}: R^{1} & =M e, R=H \\
\underline{b}: R^{1} & =M e, R=C_{2} P h \\
\underline{c}: & R^{1}=H, R=C_{2} H_{2} P h
\end{aligned}
$$

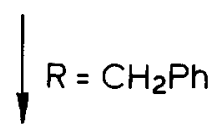

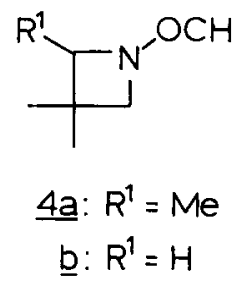

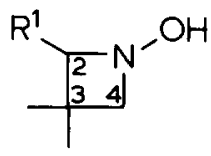

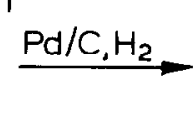

5a: $R^{1}=M e$

zyloxy-2,3,3-trimethylazetidine 4 a in a yield of 638 (b.p. $62-64^{\circ} \mathrm{C} / 0.5 \mathrm{~mm} \mathrm{Hg} ; \mathrm{n}_{\mathrm{D}}^{20}$ $1.4909)^{9}$. MS: $\mathrm{M}^{+} 205.15\left(\mathrm{C}_{13} \mathrm{H}_{19} \mathrm{NO}\right) \cdot{ }^{1} \mathrm{H}$ NMR $\delta\left(\mathrm{CDCl}_{3}\right) 3.27(\mathrm{~g}, 1 \mathrm{H}, \mathrm{H}-2), 3.02$ and 3.35 $(\mathrm{AB}, 2 \mathrm{H}, J=7 \mathrm{~Hz}, \mathrm{H}-4) .{ }^{13} \mathrm{C} \mathrm{NMR} \delta\left(\mathrm{CDCl}_{3}\right) 30.4(\mathrm{~s}, \mathrm{C}-3), 68.3(t, \mathrm{C}-4), 73.8(\mathrm{~d}, \mathrm{C}-2)$. Catalytic debenzylation of 4 a with $\mathrm{Pd} / \mathrm{C}$ in acetic acid afforded the l-hydroxyazetidine $\frac{5 a}{1}$ in a yleld of 718 (b.p. $\left.58-60^{\circ} \mathrm{C} / 5 \mathrm{~mm} \mathrm{Hg}, \mathrm{n}_{\mathrm{D}}^{20} 1.4363\right)$. MS: $\mathrm{M}^{+} 115.10\left(\mathrm{C}_{6} \mathrm{H}_{13}{ }^{\mathrm{NO}}\right)$. ${ }_{\mathrm{H}} \mathrm{NMR} \delta\left(\mathrm{CDCl}_{3}\right) 3.25(\mathrm{q}, \mathrm{lH}, \mathrm{H}-2), 3.06$ and $3.37(\mathrm{AB}, 2 \mathrm{H}, J=7.3 \mathrm{~Hz}, \mathrm{H}-4), 6.9(\mathrm{bs}, 1 \mathrm{H}, \mathrm{OH})$. ${ }^{13} \mathrm{C}$ NMR $\delta\left(\mathrm{CDCl}_{3}\right) 30.7(\mathrm{~s}, \mathrm{c}-3), 69.3(t, \mathrm{C}-4), 74.7(\mathrm{~d}, \mathrm{C}-2)$.

In a similar way, oxime lc was prepared from 2,2-dimethyl-3-tosyloxypropanal 10 and 0 -benzylhydroxylamine in a yield of 968 (oil). Reduction of the crude oxime lc as described for 1 a gave the hydroxylamine derivative $\underline{2 c}$ in a yield of 928 (oil). However, $\underline{2 c}$ did not undergo cyclization even on prolonged reaction in acetic acid, and could be characterized as the hydrochloride (m.p. 110-119 $\mathrm{C}$, dec., from chlororoform/ethyl acetate) ${ }^{9}$. Without further purification $2 \mathrm{c}$ was cyclized in diethyl ether at $20^{\circ} \mathrm{C}$ by the rapid addition of a n-butyl lithium solution in hexane, to the 1-benzyloxyazetidine $4 \mathrm{~b}$ in a yield of 538 (b.p. $\left.62-64^{\circ} \mathrm{C} / 0.6 \mathrm{~mm} \mathrm{Hg}, \mathrm{n}_{\mathrm{D}}^{20} 1.4960\right)^{9}$. MS: $\mathrm{M}^{+} 191.13\left(\mathrm{C}_{12} \mathrm{H}{ }_{17} \mathrm{NO}\right) \cdot 1_{\mathrm{H}} \mathrm{NMR} \delta\left(\mathrm{CDCl}_{3}\right) 1.17\left(\mathrm{~s}, 6 \mathrm{H}, \mathrm{CH}_{3}\right), \sim 3.3\left(\mathrm{bs}, 4 \mathrm{H}, \mathrm{NCH}_{2}\right) \cdot 13 \mathrm{C}$ NMR $\delta\left(\mathrm{CDCl}_{3}\right) 28.5(\mathrm{~s}, \mathrm{C}-3), 70.3\left(\mathrm{t}, \mathrm{NCH}_{2}\right)$. Debenzylation of $4 \underline{b}$ afforded $3,3-$ dimethyl-1-hydroxyazetidine $(\underline{5 b})$ in a yield of 61 q (b.p. $\left.56-58^{\circ} \mathrm{C} / 5 \mathrm{~mm} \mathrm{Hg}, \mathrm{n}_{\mathrm{D}}^{20} 1.4359\right)$. MS: $\mathrm{M}^{+} 101.08\left(\mathrm{C}_{5} \mathrm{H}_{11} \mathrm{NO}\right) .{ }^{1} \mathrm{H} \mathrm{NMR} \delta\left(\mathrm{CDCl}_{3}\right) 1.19\left(\mathrm{bs}, 6 \mathrm{H}, \mathrm{CH}_{3}\right), \sim 3.4\left(\mathrm{bAB}, 4 \mathrm{H}, \mathrm{NCH}_{2}\right)$, $\sim 7.6$ (bs, $1 \mathrm{H}, \mathrm{OH}) .{ }^{13} \mathrm{C} \mathrm{NMR} \delta\left(\mathrm{CDCl}_{3}\right) 28.1(\mathrm{~s}, \mathrm{C}-3), 71.3\left(t, \mathrm{NCH}_{2}\right)^{13}$.

oxidation of 1-hydroxyazetidine 5 a with yellow mercury(II)oxide in dichloromethane gave an oil, which according to ${ }^{1} \mathrm{H}$ NMR spectroscopy contained $\sim 308$ of the nitrone $6 \mathrm{a}$. The absorptions in the ${ }^{1} \mathrm{H}$ NMR spectrum at $\delta 1.32$ (s), $\delta 1.93(t, J=1.95 \mathrm{~Hz}$, and $\delta 3.96(\mathrm{~g}, J=1.95 \mathrm{~Hz})$ are in good agreement with those reported previously by Black et al. ${ }^{7}$. Obviously this method of oxidation is to drastic, since nitrone 6 a was strongly contaminated ( 708) with products that arise from decomposition or polymerization. Oxidation of $\underline{5 a}$ with "active lead(IV)oxide"14, which has been used for the preparation of sensitive and unstable nitrones from the corresponding hydroxylamines, gave a mixture of two isomeric four-membered cyclic nitrones in quan- 

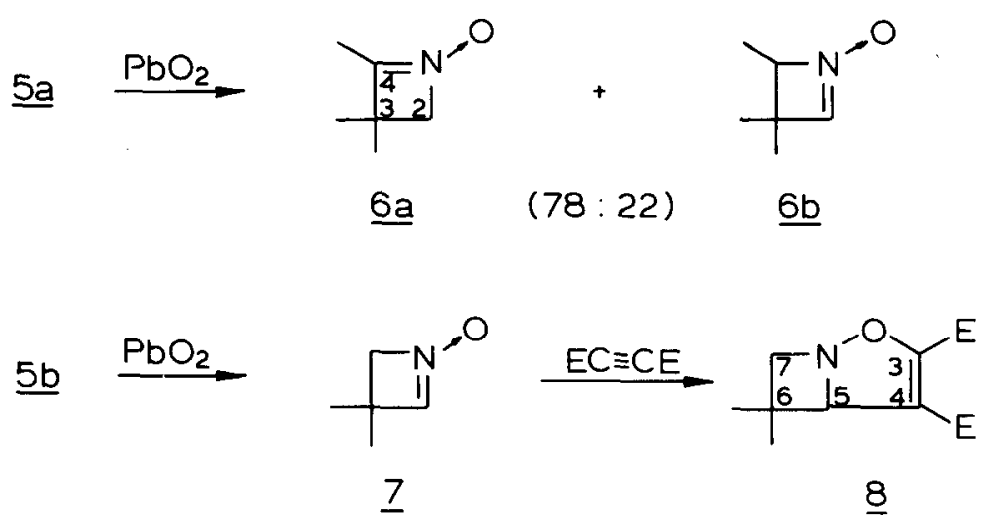

titative yield. According to ${ }^{1} \mathrm{H}$ NMR spectroscopy in addition to $6 \mathrm{a}$ ( 788 ) a second nitrone (6b) was formed (228) by a different mode of hydrogen abstraction. ${ }^{1} \mathrm{H}$ NMR $\delta\left(\mathrm{CDCl}_{3}\right) 1.23$ and $1.36\left(\mathrm{~s}, 6 \mathrm{H}, \mathrm{CH}_{3}\right), 1.41\left(\mathrm{~d}, 3 \mathrm{H}, \mathrm{CH}_{3}\right), 4.14(\mathrm{q}, 1 \mathrm{H}, \mathrm{H}-2), 6.74(\mathrm{~s}, 1 \mathrm{H}$, $\mathrm{N}=\mathrm{CH}$ ) .

Oxidation of 1-hydroxyazetidine $\underline{5 b}$, in which there is only one possible way of hydrogen abstraction gave the four-membered cyclic nitrone $\underline{Z}$ as an oil in a yield of $\sim 708 .{ }^{1} \mathrm{H} \mathrm{NMR} \delta\left(\mathrm{CDCl}_{3}\right) 1.39\left(\mathrm{~s}, 6 \mathrm{H}, \mathrm{CH}_{3}\right), 4.04(\mathrm{~s}, 2 \mathrm{H}, \mathrm{H}-2), 6.86(\mathrm{~s}, 1 \mathrm{H}, \mathrm{N}=\mathrm{CH})$. Reaction of this crude oxidation product with dimethyl acetylenedicarboxylate (DMAD) quantitatively gave the cycloadduct $\underline{8}$ (oil, purified by filtration of an ethyl acetate solution through florisil). The structure of $\underline{8}$ was proven by comparison of the ${ }^{1} \mathrm{H}$ and ${ }^{13} \mathrm{C}$ NMR spectroscopic data with those of similar cycloadducts of four-membered cyclic nitrones with DMAD ${ }^{15}$. MS: $\mathrm{M}^{+} 241.09\left(\mathrm{C}_{11} \mathrm{H}_{15} \mathrm{NO}_{5}\right) \cdot{ }^{1} \mathrm{H}$ NMR $\delta\left(\mathrm{CDCl} 1_{3}\right) 1.14$ and $1.45\left(\mathrm{~s}, 6 \mathrm{H}, \mathrm{CH}_{3}\right), 3.62$ and $3.79(\mathrm{dAB}, 2 \mathrm{H}, J=10 \mathrm{~Hz}, J \sim 1 \mathrm{~Hz}, \mathrm{H}-7), 3.75$ and 3.91 ( $\mathrm{s}$, $\left.6 \mathrm{H}, \mathrm{OCH}_{3}\right), 4.82(t, 1 \mathrm{H}, J \sim 1 \mathrm{~Hz}, \mathrm{H}-5)$.

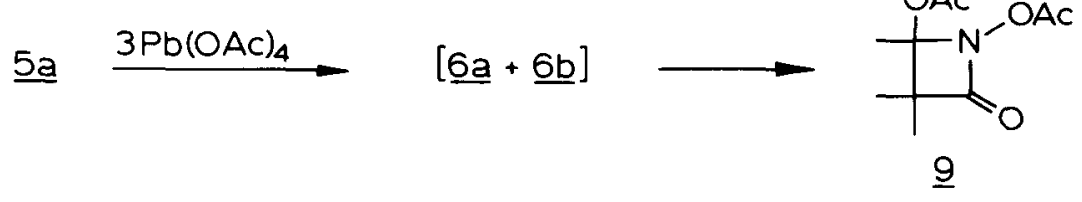

Oxidation of 1-hydroxyazetidine 5a with three equivalents of lead tetraacetate in toluene at $0^{\circ} \mathrm{C}$, produces the 1,4-diacetoxy-2-azetidinone 9 in a yield of $71 \%$ (m.p. $68.5-70^{\circ} \mathrm{C}$, from petroleum cther 60-80 $)^{9}$. MS: $\mathrm{M}^{+}+1230.10\left(\mathrm{C}_{10^{\mathrm{H}}} \mathrm{C}^{\mathrm{NO}_{5}}\right)$; IR(KBr)

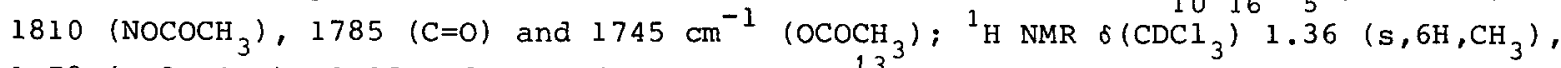
$1.78\left(5,3 \mathrm{H}, \mathrm{CH}_{3}\right), 2.07$ and $2.19\left(\mathrm{~s}, 6 \mathrm{H}, \mathrm{COCH}_{3}\right) .13 \mathrm{C} \mathrm{NMR} \delta\left(\mathrm{CDCl}_{3}\right) 55.0(\mathrm{~s}, \mathrm{C}-3), 97.2$ $(\mathrm{s}, \mathrm{C}-4), 169.0$ (s), 168.3 (s) and 167.1 (s), (C=O and $\mathrm{OC}=0)$. It has been reported in the literature that oxidation of $N, N$-dibenzylhydroxylamine proceeds $v i a$ the $n i-$ trone and also gives the corresponding diacetoxy amide derivative ${ }^{16,17}$.

The above results show that 1-hydroxyazetidines can be synthesized by cyclization of $\gamma$-tosyloxy hydroxylamine derivatives, and that they can be oxidized in good yields to the corresponding nitrones with "active $\mathrm{PbO}_{2}$ ". Oxidation with lead tetraacetate gives a 4-acetoxy-2-azetidinone derivatıve, a type of 2-azetidinone that is a precursor for biologically important bicyclic B-lactam derivatives ${ }^{18}$. 
Acknowledgement. This investigation was supported by the Netherlands Foundation for Chemical Research (SON) with financial aid from the Netherlands organization for Advancement of Pure Research (zWO).

\section{References and Notes}

1a. M.L.M. Pennings and D.N. Reinhoudt Tetrahedron Lett. $\underset{\sim}{1981}, \underline{22}, 1153$.

b. M.L.M. Pennings, D.N. Reinhoudt, S. Harkema and G.J. van Hummel J. Org. Chem., in the press.

2. M.L.M. Pennings and D.N. Reinhoudt Tetrahedron Lett. $\underset{\sim \sim \sim \sim}{1982}, 23,1003$.

3. M.L.M. Pennings and D.N. Reinhoudt J. Org. Chem. $\underset{\sim}{1982}, \underset{\sim}{47}, 1816$.

4. Two other examples of 1-hydroxyazetidines have been reported previously: R.G. Kostyanovskii, A.V. Prosyanik and V.I. Markov Chem. Abstr. 1974, 81, 25476v;

J. Harnisch and G. Szeimies Chem. Ber. 1272, 112, 3914 .

5. W.C. Lumma, JI. and O.H. Ma J. Org. Chem. $\underset{\sim}{1970}, 35,2391$.

6. This compound has been described in the literature, but spectral and physical data were not reported ${ }^{7}$.

7. D.St.C. Black, R.F.C. Brown, B.F. Dunstan and S. Sternhell Tetrahedron Lett. 1974,4283 .

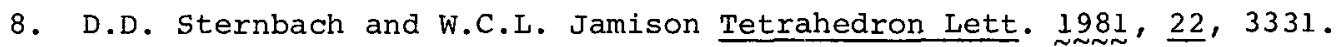

9. Satisfactory elemental analyses were obtained for this compound $(\mathrm{C}, \mathrm{H}, \mathrm{N} \pm 0.38)$.

10. This compound was prepared by oxidation of 2,2-dimethyl-3-tosyloxypropanol 11 with pyridinium chlorochromate: m.p. $67-69^{\circ} \mathrm{C}$ (dec.), from dilsopropyl ether; m.p. Lit. ${ }^{12} 61.3^{\circ} \mathrm{C}$.

11. L.J. Dolby, A. Meneghini and T. Koizumi J. Org. Chem. 1928, 33, 3060 .

12. F. Nerdel , D. Frank, H.-D. Lengert and P. Weyerstahl Chem. Ber. 1926 , 101, 1850 .

13. The methyl singlet in the ${ }^{1} \mathrm{H}$ NMR spectrum of $5 \mathrm{~b}$ at $\delta 1.19$ broadened upon cooling of the $\mathrm{CDCl}_{3}$ solution, and further cooling to about $0^{\circ} \mathrm{C}$ gave rise to two sharp singlets at $\delta 1.16$ and $\delta 1.22$. From the coalescence temperature $\left(\mathrm{T}_{\mathrm{c}}=\right.$ $\left.28^{\circ} \mathrm{C}\right)$ and the chemical shift difference of the two singlets $(\Delta \nu=4.6 \mathrm{~Hz}) \mathrm{a}$ $\Delta \mathrm{G}^{\neq}$value of $16.3 \mathrm{kcalmol}^{-1}$ for the nitrogen inversion process was calculated; a detailed study will be reported elsewhere.

14. R. Kuhn and I. Hammer Chem. Ber. 1950, 83, 413.

15. M.L.M. Pennings, G. Okay, D.N. Reinhoudt, S. Harkema and G.J. van Hummel I. org. Chem., in the press

16. L.A. Neiman, S.V. Zhukora and V.A. Tyurikov Tetrahedron Lett. 구국, 1889.

17. For a recent review of the lead tetraacetate oxidation of nitrones see: $E$. Breuer in "The Chemistry of Functional Groups", Ed. S. Patai, Interscience, 1982, Supplement F, Part I, p. 459.

18. See for instance: P.J. Reider, R. Rayford, E.J.J. Grabowski Tetrahedron Lett. $\underline{1982}, \underline{23}, 379$. 